\title{
APPLICATION OF CAPACITIVE SENSOR FOR MEASURING WATER CONTENT IN ELECTRO-INSULATING LIQUIDS
}

\section{ZASTOSOWANIE CZUJNIKA POJEMNOŚCIOWEGO DO POMIARU ZAWARTOŚCI WODY W CIECZACH ELEKTROIZOLACYJNYCH*}

\begin{abstract}
The article discusses the problem of water content measurement in electro-insulating liquids using capacitive sensors. The article describes coefficients affecting reliability of the water content measurement. The authors discussed issues connected with water saturation limit in electro-insulating liquids. The authors also proposed a method which allows determining coefficients by means of which it is possible to calculate the water saturation limit in electro-insulating liquid as a function of temperature. Determining the coefficients allows proper calculating of the water content in ppm by weight by means of relative water saturation of the investigated liquid, what was measured with a capacitive probe. Propositions included in the article improve reliability of the method to determine water content in electro-insulating liquids and thus contribute to breakdown-free operation of electric power equipment insulated with these liquids.
\end{abstract}

Keywords: capacitive sensor, water content measurement, electro-insulating liquid, transformer.

\begin{abstract}
W artykule omówiono problematyke pomiaru zawartości wody w cieczach elektroizolacyjnych przy wykorzystaniu czujników pojemnościowych. Opisano czynniki wpływające na wiarygodność pomiaru zawartości wody. Autorzy pracy omówili zagadnienia związane z granicznym nasyceniem cieczy elektroizolacyjnych woda. W artykule zaproponowana została metoda umożliwiająca wyznaczenie współczynników, za pomoca których możliwe jest obliczenie granicznego nasycenia cieczy elektroizolacyjnej woda w funkcji temperatury. Wyznaczenie współczynników umożliwia poprawne obliczenie zawartości wody w ppm wagowo za pomoca zmierzonego sonda pojemnościowa względnego nasycenia badanej cieczy woda. Propozycje zawarte w artykule poprawiaja niezawodność metody wyznaczania zawartości wody w cieczach elektroizolacyjnych, a przez to przyczyniają się do bezawaryjnej eksploatacji urzadzeń elektroenergetycznych izolowanych tymi cieczami.
\end{abstract}

Stowa kluczowe: czujnik pojemnościowy, pomiar zawartości wody, ciecz elektroizolacyjna, transformator.

\section{Introduction}

The presence of water in the electro-insulating system of power devices is a serious operational problem. This problem refers first of all to devices insulated with cellulose materials impregnated with electro-insulating liquids $[4,5]$. Examples of such devices are power transformers and instrument transformers. This problem also refers to transformer bushing insulators.

With passing years of operation of a given device, its insulation moisture rises. This problem has been discussed in different scientific publications many times $[2,4,15]$, mainly in terms of oil-paper insulation moisture of power transformers. Authors of these articles notice that water is not only a decomposition product of cellulose insulation but it also contributes to this decomposition. As a result of water presence in the insulating system and exposure to high temperature, the process of cellulose depolimerization takes place, which results in a decrease of its mechanical strength $[1,12,17]$. Other disadvantageous consequences of water presence in the insulating system are: electric strength drop of the insulation, lowering the inception voltage of partial discharges [19], and the threat of the bubble effect appearance $[8,11]$, which increases with more moistened cellulose insulation. High insulation moisture forces restrictions of the device load. One of positive aspects of water presence in solid insulation is the increase of its thermal conductivity, which to a certain extent improves cooling of the transformer windings [7]. However, negative results of water presence are predominant and there is a trend to reduce the insulation moisture of power devices as much as possible.

Due to long-lasting operation of power devices, the problem of moisture is serious and concerns not only the Polish electric power system but also the systems of most countries. The problem of insulation moisture has been known to the international community for a few decades and it is still a current issue, which is confirmed by the newest publication of the worldwide range: they concern, among others, moisture measurement methods of transformer insulation [6, $13,20]$, also problems connected with forms of water presence $[3,13$, $21]$ and its migration in the cellulose-electro-insulating liquid system $[2,15]$. Nowadays, the activities of the international CIGRE Working Group WG D1.52 Moisture measurement in insulating fluids and transformer insulation are in progress. Their purpose is, among others, to improve reliability of water content measurement methods in electro-insulating liquids.

\section{Capacitive probe for measuring water content in electro-insulating liquid}

The most frequently used method of measuring water content in electro-insulating liquids is titration method which makes use of the Karl Fischer reaction (KFT - Karl Fischer Titration). It is a standardized method [10] which is characterized by high accuracy of water content measurement. The water content measured by means of the

$\left(^{*}\right)$ Tekst artykułu w polskiej wersji językowej dostępny w elektronicznym wydaniu kwartalnika na stronie www.ein.org.pl 
KFT method is expressed in ppm by weight. In order to do the measurement of water content it is necessary to take a liquid sample from the investigated device.

In recent years strong emphasis has been put on monitoring quantities which make evaluation of the device state possible, particularly power transformers of strategic importance in power system. The devices available on the market (Fig. 1), equipped with capacitive sensors allow moisture monitoring of the electro-insulating liquid, which certainly is their great advantage.
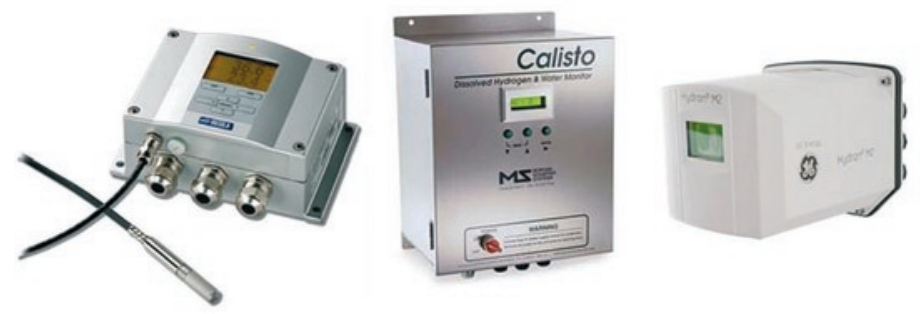

capacitive sensor, which is expressed by means of the following equation:

$$
R S=\frac{W C L}{S} \cdot 100
$$

where $W C L$ means the water content in the liquid expressed in ppm by weight, whereas $S$ means water saturation limit in the liquid, which is also expressed in ppm by weight.

Water saturation limit in the liquid should be understood as the maximum amount of water which can be dissolved in it at a given temperature. Exceeding water saturation limit in the liquid results in appearing of dispersed water. Water saturation limit depends not only on temperature but also on many other factors such as: - kind of liquid: synthetic esters $(\mathrm{S}=1758 \mathrm{ppm}$ for $\left.20^{\circ} \mathrm{C}\right)$, natural esters $\left(\mathrm{S}=858 \mathrm{ppm}\right.$ for $\left.20^{\circ} \mathrm{C}\right)$, and silicon oils $\left(\mathrm{S}=169 \mathrm{ppm}\right.$ for $\left.20^{\circ} \mathrm{C}\right)$ have much higher water solubility than mineral oils $\left(\mathrm{S}=47 \mathrm{ppm}\right.$ for $\left.20^{\circ} \mathrm{C}\right)$,

Fig. 1. Devices applied for monitoring moisture and temperature of the electro-insulating liquid, the three devices on the right side of the image can also measure some selected gases dissolved in the liquid

Figure 2 presents an example of monitoring mineral oil moisture in 160 MVA autotransformer.

It should be stressed, however, that incorrect operation of the capacitive probes can lead to wrong diagnoses concerning the state of the electric power device.

The probes mentioned before, apart from capacitive sensors, are also equipped with temperature sensors. Relative saturation $(R S)$ of the investigated liquid is determined by means of a

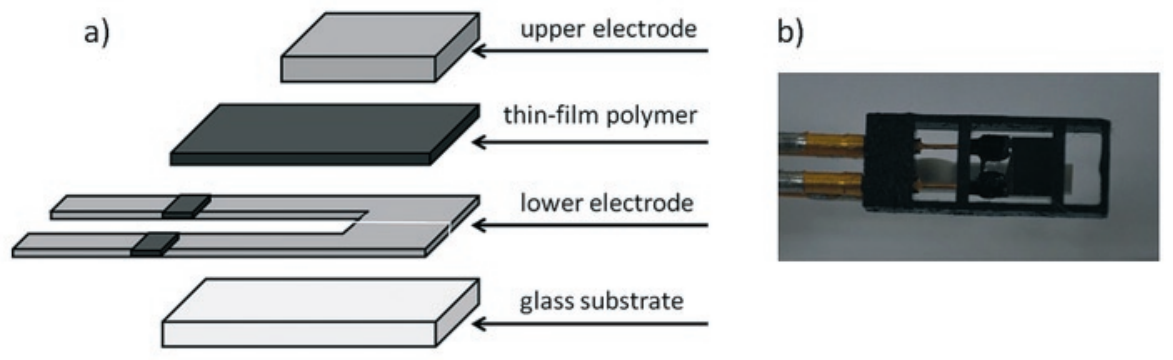

Fig. 3. Capacitive sensor: a) construction, b) photograph of the sensor [13]

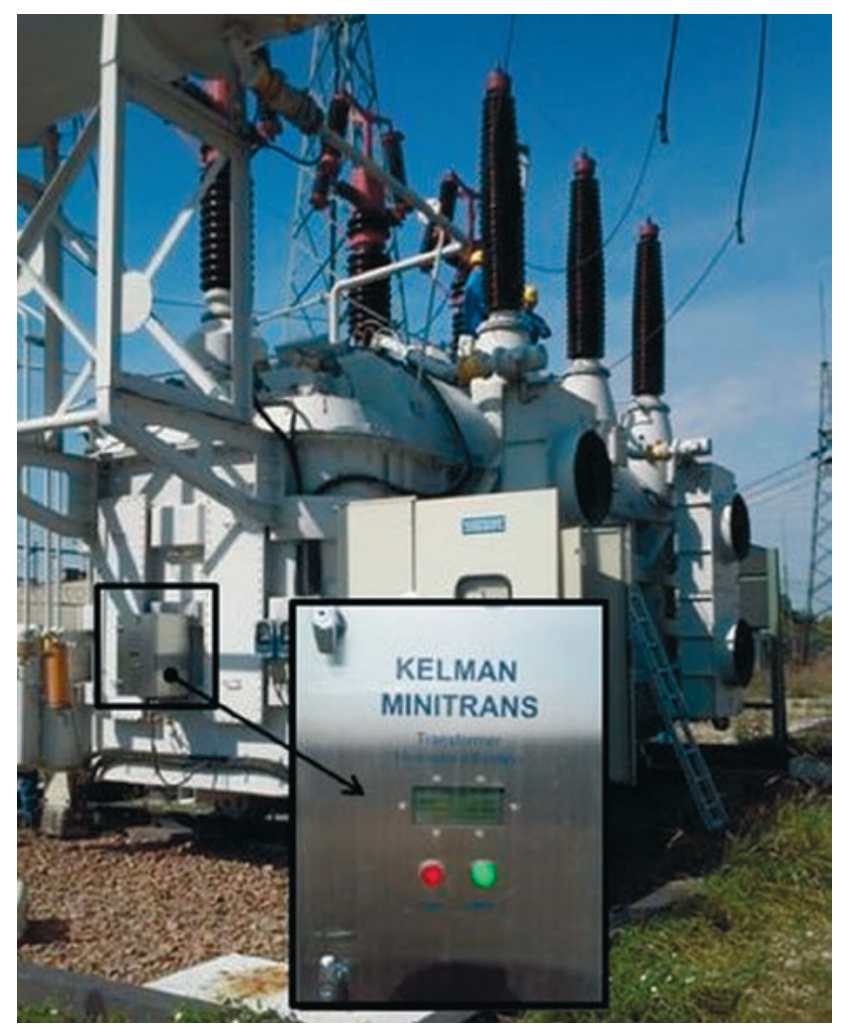

Fig. 2. Monitoring system of water and gas content in oil in 160 MVA autotransformer
- liquid composition: e.g. water solubility in mineral oil rises with an increase of the aromatic fraction content,

- ageing degree: aged liquids with the higher neutralization value, have polar ageing products, which affect water solubility increase.

Relative saturation of the liquid is measured indirectly by means of a capacitive sensor which is proportional to the sensor's capacity that is the main element of the capacitive probe. The construction of the sensor is presented in Figure 3.

The capacitive sensor consists of two electrodes between which a thin-film of hygroscopic polymer is placed. The electrodes are made in such a way so as to allow contact of the polymer with the investigated insulating liquid. Water particles present in the insulating liquid penetrate to the hygroscopic polymer, in the amount depending on relative humidity of the environment in which the sensor is immersed. Water content increase in the polymer causes increase of its electric permittivity, which in turn is connected with increase of the sensor's electric capacitance [13].

The principle of the sensor's work described above allows correct measurement of relative saturation of electro-insulating liquids. The problem appears in a situation when it is required to know the water content expressed in ppm by weight, which is enforced (not necessarily fully reasonably) by standards and operation manuals of electric power equipment $[9,16]$. There is a possibility to calculate water concentration $W C L$ in the liquid in ppm by weight on the basis of Equation (1). In order to do it, it is necessary to calculate water saturation limit in the liquid using the Arrhenius equation: 


$$
\log S(T)=A-\frac{B}{T}
$$

where A and B are coefficients characteristic for a given insulating liquid, whereas $T$ means temperature expressed in $\mathrm{K}$.

Calculating water saturation limit in the liquid is possible when coefficients A and B are known. Unfortunately, these coefficients are dependent on numerous, mentioned above factors which affect water solubility in the electro-insulating liquid. The capacitive probes fixed in the devices have a built-in algorithm which allows calculating water content in the electro-insulating liquid in ppm by weight, however, for the calculations, they most often make use of coefficients A and B, which were determined previously for a given new mineral oil. The water content measurement in ppm by weight using the capacitive probe, in liquids of different water solubility than new mineral oil, can be significantly undervalued. This is why it is necessary to determine coefficients $A$ and $B$ for liquid taken from investigated, by means of capacitive probe, electric power device.

\section{Determining coefficients A and B}

\subsection{Method description}

Within CIGRE Working Group WG D1.52 (CIGRE - Conseil International des Grands Réseaux Électriques) there are activities whose goal is to propose methods allowing reliable determination of coefficients A and B, which describe water saturation limit in electroinsulating liquids. Below is described one of the methods proposed to submit in the CIGRE brochure. The proposed method was created, among others, on the basis of experiences presented in $[3,6,13,18]$.

This method consists in conditioning of the electro-insulating liquid in a tightly closed vessel at three different temperature values. After achievement of the state of moisture equilibrium, for each temperature level the following oil parameters are measured: water content, relative saturation of the liquid and temperature. Coefficients $\mathrm{A}$ and $\mathrm{B}$ are determined on the basis of the data obtained in above described way.

\subsection{Measurement system}

The measurement system (Fig. 4) consists of a glass vessel with volume of about one litre, filled with electro-insulating liquid. The vessel should be tightly closed by means of a lid made of polytetrafluoroethylene (PTFE). Instead of glass and PTFE it is possible to use the

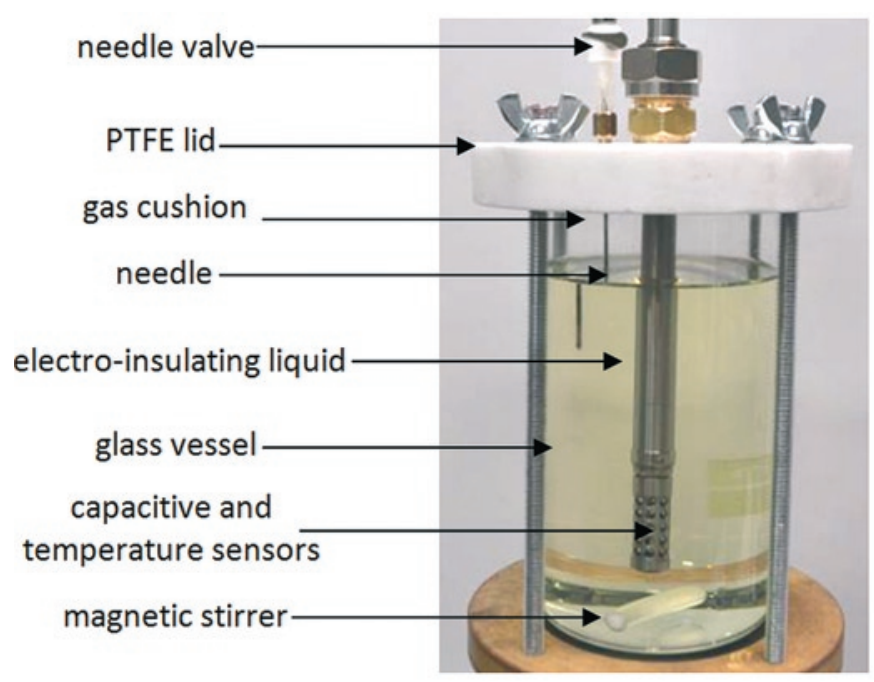

other materials which are characterized with low hygroscopicity and do not react chemically with the investigated liquid.

There are two slots in the lid. The first of them allows fixing the probe with the capacitive and temperature sensors. The other slot is for fixing the needle with the valve. A sample of the liquid is taken with the needle to measure water content by means of the Karl Fischer Titration method. In time of conditioning process the investigated liquid is mixed with the magnetic stirrer. The capacitive and temperature sensors are placed directly above the magnetic stirrer.

\subsection{Measurement procedure}

Oil conditioning is carried out for three temperature levels selected in the range from 20 to $60^{\circ} \mathrm{C}$, where the difference between the successive temperature levels should be at least $10^{\circ} \mathrm{C}$. In turn, relative saturation of the liquid in the mentioned above temperature range should be within the range from $15 \%$ (for a high value of liquid temperature) to $75 \%$ (for a low value of liquid temperature). Because of this it is necessary to do preliminary liquid moistening to the level of about $70 \%$ of relative saturation at the temperature of $20^{\circ} \mathrm{C}$. The conditioning of the vessel with oil should take place in the climatic chamber whose task is to enforce a proper temperature of the liquid. Moreover, it is recommended that after stabilizing a preset oil temperature value, the value of air relative humidity in the chamber should be set at the same level as relative saturation of the investigated liquid. This is a way to prevent water migration if leaks occur in the measurement system. After stabilizing the temperature, the needle valve should be opened for a very short time in order to rebalance the air pressure in the vessel with atmospheric pressure.

The time of liquid conditioning for each temperature level should be long enough, so that the system could reach the equilibrium state of moisture and temperature.

For each temperature level $n$, after reaching the equilibrium state, the value of relative water saturation $R S_{n}$ and temperature $T_{n}$ of the investigated liquid should be recorded. Moreover, a liquid sample should be taken and water content $W C L_{n}$ should be measured using the Karl Fischer Titration method.

Using the obtained data sets $\left(R S_{n}, T_{n}, W C L_{n}\right)$ and Equation (3) it is possible to determine coefficients $\mathrm{A}$ and $\mathrm{B}$. Equation 3 was obtained from Equations (1) and (2).

$$
\log \left(\frac{W C L_{n}}{R S_{n}} \cdot 100\right)=A-\frac{B}{T_{n}} .
$$

\subsection{Research results - example of method application}

Figure 5 presents an application of the described above procedure for determining coefficients $\mathrm{A}$ and $\mathrm{B}$ for new mineral oil. The conditioning time was equal to $24 \mathrm{~h}$ for each temperature level.

On the basis of the research results presented in Figure 5 and making use of Equation (3), coefficients $A=7.288$ and $B=1646.897$ were determined for new mineral oil. This experiment was repeated twice, and the obtained results are listed in Table 1 and in Figure 6.

On the basis of the experiment results presented in Table 1 and in Figure 6, it can be find high reproducibility of the results obtained by means of the proposed method.

For all measurements in Table 1, the authors determined expanded uncertainty $U(S)$ for the confidence level $\mathrm{k}=2$. The following equation was used for the calculations:

$$
U\left(S_{n}\right)=k \cdot u_{c}\left(S_{n}\right)=k \cdot \sqrt{\left[\frac{\partial\left(\frac{W C L_{n}}{R S_{n}} \cdot 100\right)}{\partial W C L_{n}} \cdot u(W C L)\right]^{2}+\left[\frac{\partial\left(\frac{W C L_{n}}{R S_{n}} \cdot 100\right)}{\partial R S_{n}} \cdot u(R S)\right]^{2}} .
$$

Fig. 4. Measurement system for determining coefficients $A$ and $B$ [14] 
Table 1. Comparison of coefficients $A$ and B, and water saturation limit S in mineral oil, calculated on their basis

\begin{tabular}{|c|c|c|c|c|c|c|c|c|c|c|c|}
\hline Temperature $\left[{ }^{\circ} \mathrm{C}\right]$ & 0 & 10 & 20 & 30 & 40 & 50 & 60 & 70 & 80 & 90 & 100 \\
\hline $\begin{array}{c}\text { Measurement } 1- \\
\mathrm{A}=7.288, \mathrm{~B}=1646.897 \\
\mathrm{~S} \pm \mathrm{U}(\mathrm{S})[\mathrm{ppm}]\end{array}$ & $18 \pm 2$ & $30 \pm 3$ & $47 \pm 4$ & $72 \pm 7$ & $107 \pm 10$ & $155 \pm 15$ & $221 \pm 21$ & $308 \pm 30$ & $421 \pm 42$ & $566 \pm 57$ & $749 \pm 76$ \\
\hline $\begin{array}{c}\text { Measurement } 2 \text { - } \\
\mathrm{A}=7.246, \mathrm{~B}=1635.942 \\
\mathrm{~S} \pm \mathrm{U}(\mathrm{S})[\mathrm{ppm}]\end{array}$ & $18 \pm 2$ & $29 \pm 3$ & $46 \pm 4$ & $71 \pm 7$ & $105 \pm 10$ & $153 \pm 15$ & $216 \pm 21$ & $301 \pm 30$ & $411 \pm 42$ & $551 \pm 57$ & $727 \pm 76$ \\
\hline $\begin{array}{c}\text { Measurement } 3- \\
\mathrm{A}=7.342, \mathrm{~B}=1662.676 \\
\mathrm{~S} \pm \mathrm{U}(\mathrm{S})[\mathrm{ppm}]\end{array}$ & $18 \pm 2$ & $30 \pm 3$ & $47 \pm 4$ & $72 \pm 7$ & $108 \pm 10$ & $157 \pm 15$ & $224 \pm 22$ & $314 \pm 31$ & $430 \pm 43$ & $580 \pm 58$ & $769 \pm 78$ \\
\hline
\end{tabular}

U(S) - expanded uncertainty

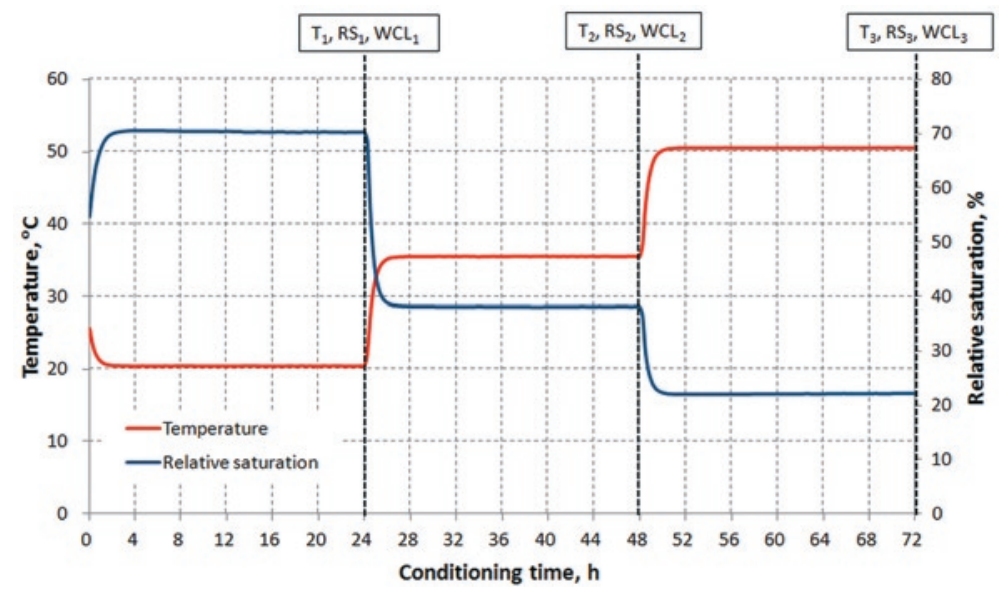

Fig. 5. Procedure for determining coefficients $A$ and $B$; results obtained for new mineral oil: $T_{1}=20.47^{\circ} \mathrm{C}, \quad R S_{1}=70.21 \%, \quad W C L_{1}=33.6$ ppm; $T_{2}=35.54^{\circ} \mathrm{C}, R S_{2}=38.17 \%, \quad W C L_{2}=34.2 \mathrm{ppm} ; T_{3}=50.59^{\circ} \mathrm{C}$, $R S_{3}=22.25 \%, W_{C L}=35.4 \mathrm{ppm}$

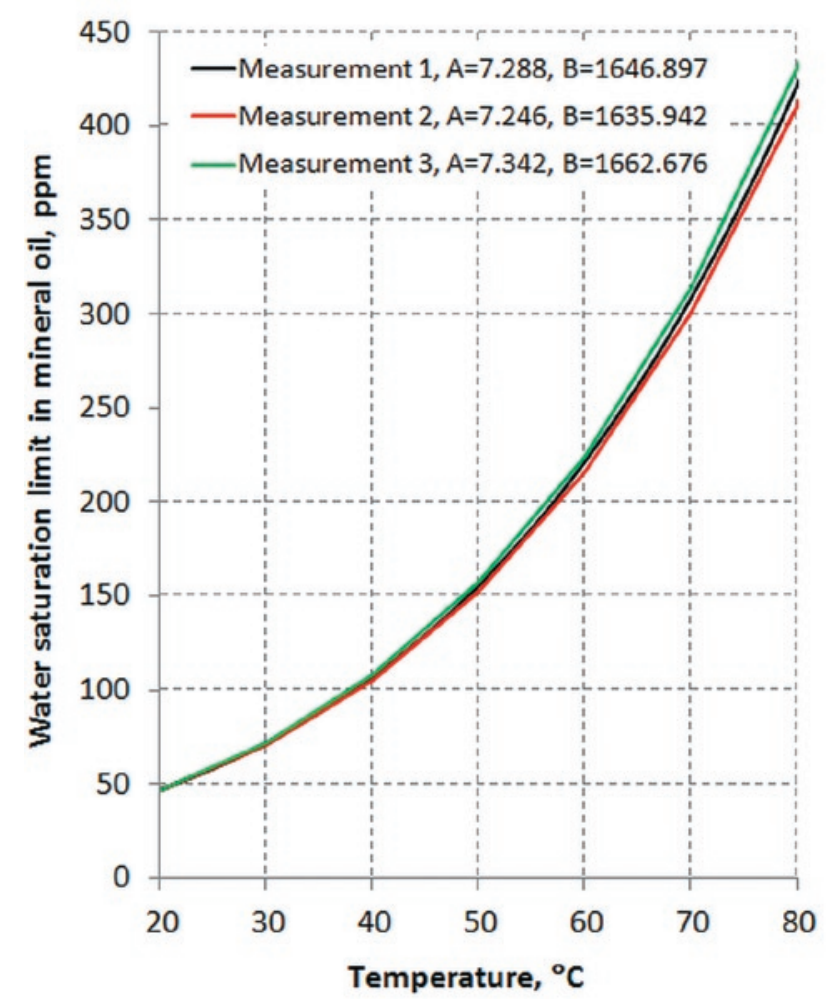

Fig. 6. Comparison of measurement results of water saturation limit in new mineral oil as a function of temperature
In order to determine measurement uncertainty of water saturation limit in mineral oil, standard uncertainty of the water content measurement using the KFT method equal to $\mathrm{u}(\mathrm{WCL})=1,5$ ppm as well as standard uncertainty of the measurement of relative saturation of oil equal to $\mathrm{u}(\mathrm{RS})=0,5 \%$ was assumed. The uncertainty range for measurement 1 of water saturation limit in mineral oil is presented in Figure 7.

It should be noted that reliability of the coefficients A and B allowing description of water saturation limit in electro-insulating liquid as a function of temperature is highly affected by accuracy of the water content measurement using the Karl Fischer Titration method. Even a slight measurement mistake can cause a significant error of the determined water solubility, particularly in the range of high temperature values.

\section{Conclusions}

The authors propose a method for determining coefficients A and $\mathrm{B}$ which allow description of water solubility in the electroinsulating liquid as a function of temperature. The knowledge of water solubility as a function of temperature is needed when it is necessary to recalculate relative saturation of the investigated liquid, measured by means of the capacitive sensor, into water content expressed in ppm by weight.

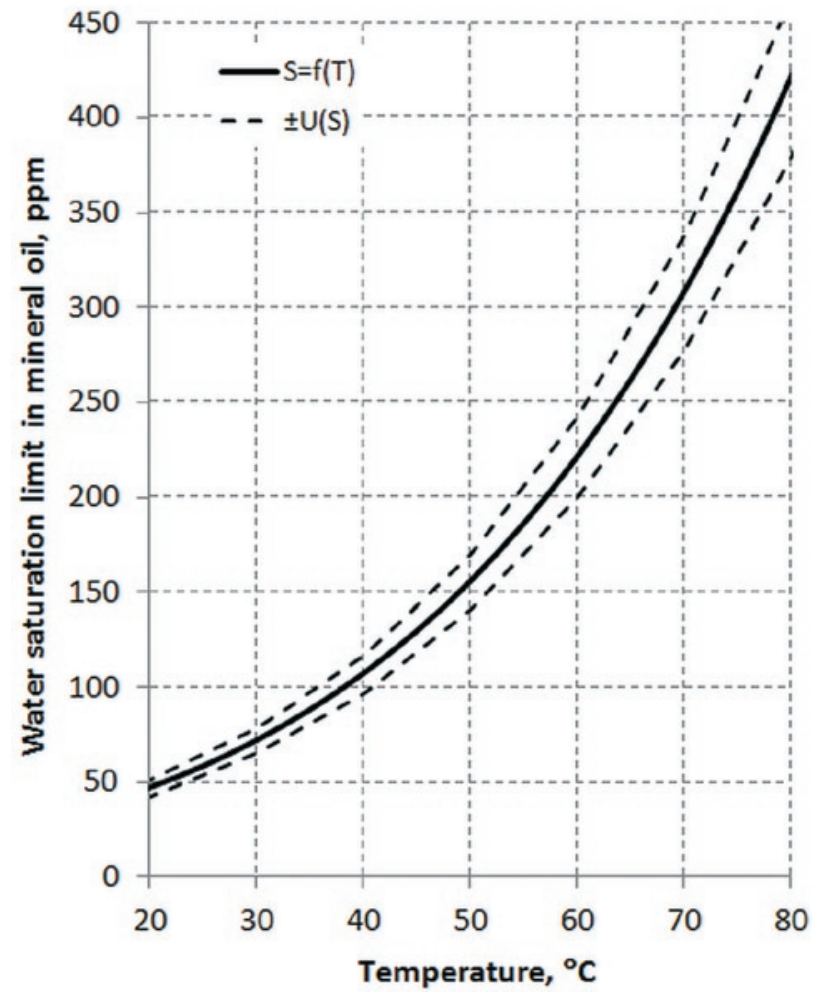

Fig. 7. Uncertainty range of water saturation limit in mineral oil: $S=f(T)-$ result of water saturation limit in oil for measurement 1 (Table 1), $U(S)$ - expanded uncertainty 
The article presents a procedure for determining coefficients using new mineral oil as an example. However, it should be emphasized that determined coefficient values are correct only for the mineral oil investigated within the experiment. Their application for other electro-insulating liquids, particularly aged mineral oils, silicon oils and esters will make results of water content in ppm by weight significantly undervalued.

The research done so far allow to claim that the presented method for determining coefficients, which are used for description of water solubility as a function of temperature, can be applied for different electro-insulating liquids, such as: mineral oils, silicon oils, synthetic and natural esters. The authors found high reproducibility of results obtained using the above described method.

\section{Acknowledgement}

The research was financed from resources of the Ministry of Science and Higher Education for statutory activities No 04/41/DS-PB/4181, name of the task: Water solubility in electro-insulating liquids measurement procedure, determining coefficients which allow calculating water solubility in mineral oil as a function of temperature.

\section{References}

1. Cigré Brochure 323, Ageing of cellulose in mineral-oil insulated transformers, 2007.

2. Cigré Brochure 349, Moisture equilibrium and moisture migration within transformer insulation systems, 2008.

3. Fofana I., Arakelian V.G., Water in oil-filled high-voltage equipment, Part I: States, Solubility, and Equilibrium in Insulating Materials, IEEE Electrical Insulation Magazine 2007; 23(4): 15-27, http://dx.doi.org/10.1109/MEI.2007.386480.

4. Gielniak J., Graczkowski A., Morańda H., Przybylek P., Walczak K., Nadolny Z., Moscicka-Grzesiak H., Gubanski S.M., Feser K., Moisture in cellulose insulation of power transformers: statistics, IEEE Transactions on Dielectrics and Electrical Insulation 2013; 20(3): 982-987, http://dx.doi.org/10.1109/TDEI.2013.6518968.

5. Gielniak J., Przybylek P., Moisture distribution in RBP bushing core (Rozkład zawilgocenia w rdzeniu izolatora przepustowego o izolacji typu RBP), in proc. of the X Conference Power and Special Transformers (Transformatory Energetyczne i Specjalne), 2014; 51-60 (in Polish).

6. Gradnik T., Koncan-Gradnik M., Petric N., Muc N., Experimental evaluation of water content determination in transformer oil by moisture sensor, in proc. of the IEEE International Conference on Dielectric Liquids (ICDL) 2011; 1-4, http://dx.doi.org/10.1109/icdl.2011.6015440.

7. Lopatkiewicz R., Nadolny Z., Przybylek P., The influence of water content on thermal conductivity of paper used as transformer windings insulation, in proc. of the 10th IEEE International Conference on the Properties and Applications of Dielectric Materials (ICPADM) 2012; 1-4, http://dx.doi.org/10.1109/icpadm.2012.6318991.

8. Oommen T.V., Lindgren S.R., Bubble evolution from transformer overload, in proc. of the Transmission and Distribution Conference and Exposition 2001; 137-142.

9. IEC 60422, Mineral insulating oils in electrical equipment. Supervision and maintenance guidance, 2006.

10. IEC 60814, Insulating liquids - Oil-impregnated paper and pressboard - Determination of water by automatic coulometric Karl Fischer titration, 2002.

11. Przybylek P., Investigations of the temperature of bubble effect initiation in oil-paper insulation (Badania temperatury inicjacji efektu bąbelkowania w izolacji papier-olej), Przeglad Elektrotechniczny (Electrical Review) 2010; 86(11B): 166-169 (in Polish).

12. Przybylek P., Moscicka-Grzesiak H., The influence of water content and ageing degree of paper insulation on its mechanical strength, in proc. of the 10th IEEE International Conference on the Solid Dielectrics (ICSD) 2010; 1-3, http://dx.doi.org/10.1109/icsd.2010.5568018.

13. Przybylek P., Water solubility in insulating liquids in aspect of moisture investigation using capacitive sensor (Rozpuszczalność wody w cieczach izolacyjnych w aspekcie badania ich zawilgocenia przy użyciu sondy pojemnościowej), Przeglad Elektrotechniczny (Electrical Review) 2012; 88(11A): 347-350 (in Polish).

14. Przybylek P., Siodla S., Determination of water solubility coefficients - text proposal for the Brochure, materiał niepublikowany opracowany na potrzeby grupy roboczej CIGRE D1.52, Helsinki 2015.

15. Przybylek P., The influence of temperature and cellulose polymerization degree on water distribution in oil-paper insulation, IEEE Transactions on Dielectrics and Electrical Insulation 2013; 20 (2): 552-556, http://dx.doi.org/10.1109/TDEI.2013.6508758.

16. Frame Instruction of Transformers Exploitation (Ramowa Instrukcja Eksploatacji Transformatorów), ZPBE Energopomiar, Gliwice, 2012 (in Polish).

17. Shroff D.H., Stannett A.W., A review of paper aging in power transformers, in the IEE Proceedings C. Generation, Transmission and Distribution 1985; 132(6): 312-319, http://dx.doi.org/10.1049/ip-c.1985.0052.

18. Vaisala HUMICAP Moisture and Temperature Transmitter Series HMT330 - User's Guide, 2008.

19. Ziomek W., Kuffel E., Sikorski W., Staniek P., Siodła K., Location and recognition of partial discharge sources in a power transformer using advanced acoustic emission method, Przeglad Elektrotechniczny (Electrical Review) 2008; 10/2008(84): 20-23.

20. Żukowski P., Kołtunowicz T.N., Kierczyński K., Subocz J. Szrot M., Gutten M., Sebok M., Jurcik J., An analysis of AC conductivity in moist oil-impregnated insulation pressboard, IEEE Transactions on Dielectrics and Electrical Insulation 2015; 22(4): 2156-2164, http://dx.doi. org/10.1109/TDEI.2015.004606.

21. Żukowski P., Kołtunowicz T.N., Kierczyński K., Subocz J. Szrot M., Formation of water nanodrops in cellulose impregnated with insulating oil, Cellulose 2015, 22(1): 861-866, http://dx.doi.org/10.1007/s10570-015-0543-0.

\section{Piotr PRZYBYŁEK}

Krzysztof SIODŁA

Institute of Electric Power Engineering

Poznan University of Technology

ul. Piotrowo 3a, 60-965 Poznań, Poland

E-mails: piotr.przybylek@put.poznan.pl, krzysztof.siodla@put.poznan.pl 